\title{
Identification of Enteric Bacterial Pathogens in Beverages Sold By Hawkers around Jatinangor, Bandung
}

\author{
Teow Sheng Hao, ${ }^{1}$ Yanti Mulyana, ${ }^{2}$ Bachti Alisjahbana ${ }^{3}$ \\ ${ }^{1}$ Faculty of Medicine Universitas Padjadjaran, Indonesia, ${ }^{2}$ Department of Biomedical Sciences \\ Faculty of Medicine Universitas Padjadjaran, Indonesia, ${ }^{3}$ Department of Internal Medicine Faculty \\ of Medicine Universitas Padjadjaran/Dr. Hasan Sadikin General Hospital, Bandung, Indonesia
}

\section{Abstract}

Background: Water is essential for life and is considered as a medium for the propagation and dissemination of bacteria. Water-borne disease is one of the problems in Indonesia, therefore, this study was conducted to explore the presence of enteric bacterial pathogens in the beverages sold by hawkers.

Methods: A descriptive laboratory method was conducted in September 2015 Beverages were collected from hawkers that were randomly chosen around Jatinangor using sterile containers, and brought to the laboratory within 1 hour. The beverages were incubated on Mueller Hinton Broth, followed by culturing on MacConkey Agar. The organisms were identified using Gram Staining, Kliger Test, Motility-Indole-Urease test and Citrate test.

Results: Out of 30 samples collected, 2 of the samples were tested positive for enteric bacterial pathogen Salmonella paratyphi. Furthermore, Klebsiella pneumoniae $(\mathrm{n}=12)$, Enterobacterspp $(\mathrm{n}=10)$ Alcaligenes faecalis $(\mathrm{n}=3)$ and Pseudomonas spp. $(\mathrm{n}=3)$ were detected in the samples.

Conclusions: The Salmonella paratyphi as enteric bacterial pathogen found in the beverages sold by hawkers has potential to cause water-borne disease. Education to hawkers need to be enhanced.

Keywords: Beverages, Enteric Bacterial Pathogens, Hawkers, Salmonella paratyphi

\section{Introduction}

Water is indisputably essential in life. All of our body systems depend highly on water, such as in carrying nutrients, eliminating toxin from vital organ and for crucial cellular homeostasis. ${ }^{1}$ Nonetheless, it is also considered as a primary medium for the propagation and dissemination of bacteria. Therefore, ingestion of water contaminated by opportunistic pathogenic environmental bacteria may ensue in some serious health implications of waterborne disease. Reports have shown that the incidence of waterborne diseases caused by microorganisms, including the common diarrhea-caused by Enterobacteriaceae, has significantly increased over the past few decades. ${ }^{2}$ Safe drinking water has then become one of our primary fundamental right ever since. Thus, the importance of prevention against microbial contamination in drinking water is substantially emphasized. ${ }^{3}$

A report of WHO/UNICEF Joint Monitoring Programme for Water Supply and Sanitation 2012 has been introduced to highlight water supply, sanitation, and hygiene development as its main focuses. ${ }^{4}$ Based on the report, Indonesia has over 110 million of the population that has left without proper sanitation and nearly 63 million are still practicing open defecation..$^{5}$ Furthermore, about 43 million of people fending without an access to clean water supplies. Consequently, it led to a surge in cases of water-related diseases and worst, some may even result in mortality. ${ }^{6}$

This study was conducted with the purpose of improving the quality of life and saving lives in the near future. Hence, the primary aim of the study was to detect the presence of enteric bacterial pathogens in the beverages sold by hawkers around Jatinangor.

Correspondence: Teow Sheng Hao, Faculty of Medicine Universitas Padjadjaran,Jalan Raya Bandung-Sumedang Km.21, Jatinangor, Sumedang, Indonesia, Email: oysterteow@hotmail.com 


\section{Methods}

This descriptive study was carried out in the Microbiology Laboratory of Faculty of Medicine from September to November 2015. A total of 30 samples were collected from randomly chosen hawkers around Jatinangor, who did not keep the beverages in the fridge. Beverages were defined as drinks made by the hawkersthemshelves. The standard of the beverages was tea with milk, tea with sugar and syrup drink. No ice cubes were present in the drinks. This study protocol was approved by the Health Research Ethics Committee, Faculty of Medicine, UniversitasPadjadjaran.

All the samples were collected in clean containers and were brought to the laboratory within an hour. The samples were incubated in Mueller Hinton broth at the temperature of $37^{\circ} \mathrm{C}$ for 24 hours. Followed by culture, the samples were then spread on MacConkey agar and incubated in $37^{\circ} \mathrm{C}$ for 24 hours. Observations were made to detect growing colonies on the MacConkey. Next, the colonies were collected using a sterile inoculating loop and smeared on the slide for gram staining. These Gram staining procedures used crystal violet solution, iodine solution, alcohol $96 \%$ and safranin. The suspected colony was first mixed with $\mathrm{NaCl} 0.9 \%$. After it became a dry suspension, the suspected colony was mixed with crystal violet solution for 1 minute to stain the cell purple. The slide was rinsed with tap water and poured with iodine solution for 1 minute to color the cells. Subsequently, the slide was rinsed again under tap water and later decolorized by using alcohol $96 \%$. Lastly, safranin was added for another 1 minute. The end result would either show a color of pink or red which indicate the presence of gram negative cells.

Meanwhile, Enteropathogenic bacteria in particular were identified under a microscope using high-powered 100x objective lens with a drop of immersed oil. Following the Gram staining, three more biochemical tests were done using Kliger Iron Agar test (KIA), Motility Indole Urease test (MIU) and the citrate test. Small amount of bacteria colony was streaked in the 3 medium and was incubated in $37^{\circ} \mathrm{C}$ for 24 hour. The bacteria were identified by their distinguished appearances according to the specific biochemical test.

\section{Results}

Furthermore, the presence of several types of bacteria such as Klebsiellapneumoniae, Enterobacterspp, Alcaligenesisfaecalis, Salmonella paratyphiand Pseudomonas spp, were also successfully identified (Table 1). Stratification were used to classified bacteria types into pathogenic and non-pathogenic. Pathogenic bacteria, in this study was found

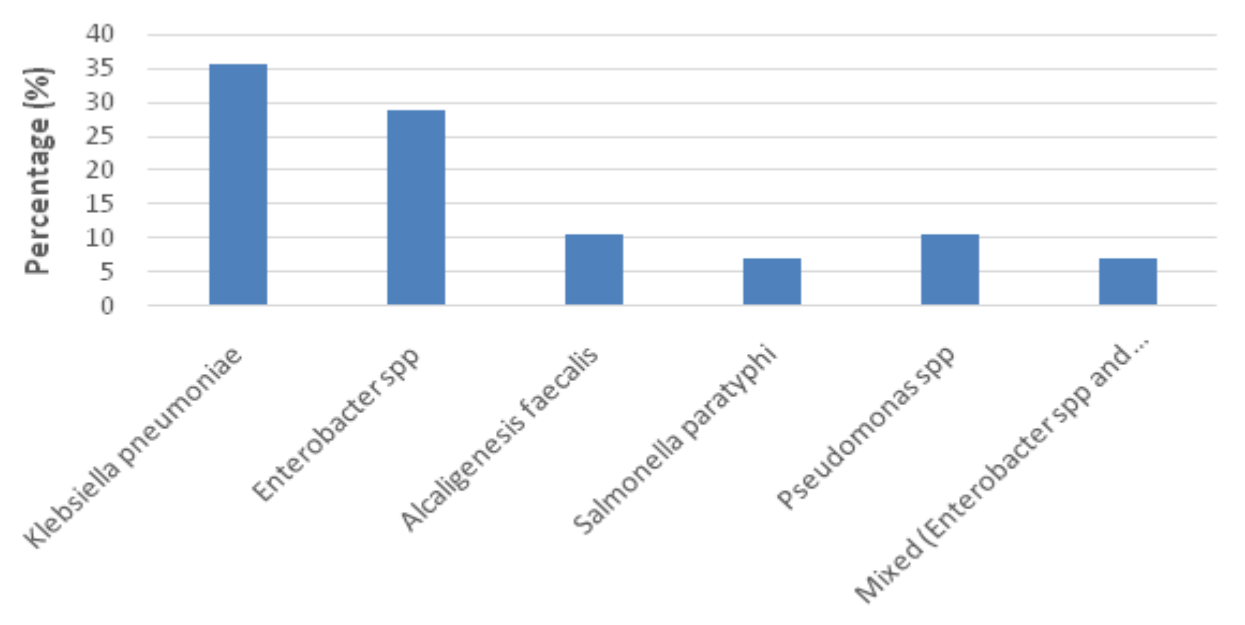

Types of Bacteria Found in Beverages

Figure 1 Number of Cases According to Types of Bacteria Found in Beverages 
Table 1 Types of Bacteria Present in Beverages Sold by Hawkers around Jatinangor, Bandung

\begin{tabular}{|c|c|c|}
\hline Beverages & Identification Results & Type of Bacteria \\
\hline Syrup drinks & Negative & - \\
\hline Tea with milk & Negative & - \\
\hline Syrup drinks & Negative & Alcaligenesisfaecalis \\
\hline Tea with milk & Negative & Alcaligenesisfaecalis \\
\hline Tea with sugar & Negative & Alcaligenesisfaecalis \\
\hline Syrup drinks & Lactose (+) Mobility (+) Citrate (+) & Enterobacterspp \\
\hline Syrup drinks & Lactose (+) Mobility (+) Citrate (+) & Enterobacterspp \\
\hline Syrup drinks & Lactose (+) Mobility (+) Citrate (+) & Enterobacterspp \\
\hline Syrup drinks & Mobility (+) Citrate $(+)$ & Enterobacterspp \\
\hline Tea with milk & Lactose (+) Mobility (+) Citrate (+) & Enterobacterspp \\
\hline Tea with milk & Mobility (+) Citrate $(+)$ & Enterobacterspp \\
\hline Tea with sugar & Mobility (+) Citrate $(+)$ & Enterobacterspp \\
\hline Tea with sugar & Lactose (+) Mobility (+) Citrate (+) & Enterobacterspp \\
\hline Tea with milk & $\begin{array}{l}\text { (A)Mobility (+) Citrate }(+) \\
\text { (B) Lactose }(+) \text { Citrate }(+)\end{array}$ & $\begin{array}{l}\text { Enterobacterspp } \\
\text { Klebsiella pneumoniae }\end{array}$ \\
\hline Tea with sugar & $\begin{array}{l}\text { (A) Mobility }(+) \text { Citrate }(+) \\
\text { (B) Lactose }(+) \text { Citrate }(+)\end{array}$ & $\begin{array}{l}\text { Enterobacterspp } \\
\text { Klebsiella pneumoniae }\end{array}$ \\
\hline Syrup drinks & Lactose $(+)$ Citrate $(+)$ & Klebsiella pneumoniae \\
\hline Syrup drinks & Lactose (+) Citrate (+) & Klebsiella pneumoniae \\
\hline Syrup drinks & Lactose (+) Citrate (+) & Klebsiella pneumoniae \\
\hline Tea with milk & Lactose (+) Citrate (+) & Klebsiella pneumoniae \\
\hline Tea with milk & Lactose $(+)$ Citrate $(+)$ & Klebsiella pneumoniae \\
\hline Tea with milk & Lactose $(+)$ Gas (+) Citrate $(+)$ & Klebsiella pneumoniae \\
\hline Tea with sugar & Lactose $(+)$ Citrate $(+)$ & Klebsiella pneumoniae \\
\hline Tea with sugar & Lactose (+) Citrate (+) & Klebsiella pneumoniae \\
\hline Tea with sugar & Lactose $(+)$ Gas $(+)$ Citrate $(+)$ & Klebsiella pneumoniae \\
\hline Tea with sugar & Lactose (+) Citrate (+) & Klebsiella pneumoniae \\
\hline Syrup drinks & Mobility $(+)$ Citrate $(+)$ & Pseudomonas spp \\
\hline Tea with milk & Mobility $(+)$ Citrate $(+)$ & Pseudomonas spp \\
\hline Tea with milk & Mobility $(+)$ Citrate $(+)$ & Pseudomonas spp \\
\hline Tea with sugar & Mobility (+) & Salmonella paratyphi* \\
\hline Tea with sugar & Mobility (+) & Salmonella paratyphi* \\
\hline
\end{tabular}

Note: ${ }^{* *}$ were pathogenic bacteria

in 2 cases $(7.1 \%)$ whereas the rest of 26 cases (92.9\%) were non-pathogenic bacteria (Table 1) .

As a result, a crucial pattern on the types of bacteria frequently encountered in the beverages, from the least to the commonest, was able to be deduced (Figure 1). The commonest bacteria found were Klebsiella pneumoniae (35.7\%) followed by Enterobacterspp (287\%), Alcaligenesisfaecalis (10.7\%), Pseudomonas spp $(10.7 \%)$ and Salmonella paratyphi (7.1\%). However, there were also $7.1 \%$ of mixed growth between Enterobacter spp and Klebsiellapneumoniae. 
Table 2 Types of Beverages Contaminated with Various Bacteria

\begin{tabular}{lcc}
\hline \multicolumn{1}{c}{ Beverages } & Type of Bacteria & $\mathbf{N}$ \\
\hline Syrup drinks & None detected & 1 \\
& Alcaligenesisfaecalis & 1 \\
& Enterobacterspp & 4 \\
& Klebsiella pneumoniae & 3 \\
Pseudomonas spp & 1 \\
Nea with milk & None detected & 1 \\
& Alcaligenesisfaecalis & 1 \\
& Enterobacterspp & 2 \\
Enterobacterspp & 1 \\
Klebsiella pneumoniae & 3 \\
& Pseudomonas spp & 2 \\
& Alcaligenesisfaecalis & 1 \\
& Enterobacterspp & 2 \\
& Enterobacterspp & 1 \\
& Klebsiella pneumoniae & 4 \\
& Salmonella paratyphi & 2 \\
\hline
\end{tabular}

\section{Discussions}

Out of 30 beverages samples collected, 28 samples $(93.3 \%)$ have been contaminated with either pathogen or non-pathogen bacteria. Such results may depict that hawkers in Jatinangor are majorly serving contaminated beverages to its customers, by change. This intricately reflects that many people havebeen exposed to unwanted, yet serious health implications like waterborne diseases, after ingesting those contaminated drinks. ${ }^{7}$

Similarly, study in Pakistan $^{8}$ has shown that there is a high amount of microbial contamination found in the drinks sold by street hawkers. Unhygienic environment and poor handling practices definitely have a strong association to the microbial contamination found in the drinks. These reports also show the possibility of bacteria to be able to survive in drinks especially within the low economic areas. ${ }^{8}$

In addition, this study is able to deduce the commonest bacteria found within beverages. Klebsiella pneumoniae was the most common bacteria found in baverages (35.7\%), despite their non-pathogenic properties in gastrointestinal tract. This may be because of their non-pathogenic character. Klebsiella spp can be easily found in the respiratory tract and human feces, but they could only pose threats when they are displaced from their normal habitat. Therefore, Klebsiella spp plays only a minimal role in causing waterborne disease. ${ }^{9}$

Whilst, the second most Enterobacteriaceae that have been isolated from the beverages was Enterobacter spp. Several Enterobacter spp are known as opportunistic pathogens in human that can be found mostly on human skin and in the intestinal tract. This bacteria can barely survive in low pH environment, hence the secretion of gastric acid plays an important role in killing the bacteria. ${ }^{10}$ Thus, Enterobacter spp poses even a lower risk to cause harm to humans.

Intricately, the worst pathogen found within the beverages were Salmonella paratyphi, mostly found in animal feces. The bacteria had indeed known to be pathogenic towards human, in which one may suffer severe fever and abdominal pain. Salmonella paratyphi possess several unique characteristics that enable them to survive harsh environments, such as the ability to grow at $7-48^{\circ} \mathrm{C}$ with an optimum growth at human's body temperature of $37^{\circ} \mathrm{C}$ and at $\mathrm{pH}$ of 4 to 9.5 with an optimal growth at $\mathrm{pH} 6.5$ to 7.5.11 Therefore, Salmonella spp manage to survive in the stomach through the induction of acid 
tolerance response and the ability to undergo an adaptive response to moderately acidic $\mathrm{pH} .{ }^{12}$ The short emptying time after consume beverage could also facilitate Salmonella sppsurvival. ${ }^{13}$

The presence of enteropathogenic bacteria such as Salmonella paratyphiis correlated with poor personal hygiene and environmental sanitation, lack of supply of safe water and ignorance of health promotion practices. These may indirectly due to low education status which may lead to outbreaks of infectious diseases among the population. Other species of Enterobacteriaceae that detected is supporting the idea of contamination of fecal bacteria due to inadequate hand washing of the hawkers. The non-enterobacteriaceae that detected is commonly presence in environment such as soil and water. Relatively, indicative of poor hygiene when handling food and beverages.

This study was conducted within 3 months, which limited further collection, culturing and analyzing for even bigger sample size. With only 30 samples in total, this study was therefore insufficient to conclude that the enteric bacteria pathogen, especially Salmonella paratyphi is commonly present in beverages sold by hawkers, to be said potentially causing waterborne diseases. Moreover, the shortage of budget at hand was nearly inadequate to cover the total cost of all the microbiology examinations, especially the agar. Despite all the limitations stated, this study is still able to detect numbers of beverages containing pathogenic enteric bacteria.

In conclusion, beverages sold by hawkers possess a potential risk to cause serious health implications like waterborne diseases, especially in the presence of Salmonella paratyphi. A proper handling during beverages preparation as well as environmental sanitation are the vital factors to help in preventing further risks to consumers, thus, improving the quality of life for humans.

\section{References}

1. Popkin BM, D’Anci KE, Rosenberg IH. Water, hydration, and health. Nutr Rev. 2010;68(8):439-58.

2. Gleeson C, Gray N. The coliform index and waterborne disease: problems of microbial drinking water assessment: London; CRC Press; 2002.

3. Matilainen A, Vepsäläinen M, Sillanpää
M. Natural organic matter removal by coagulation during drinking water treatment: A review. Adv Colloid Interface Sci. 2010;159(2):189-97.

4. UNICEF, WHO. Progress on drinking-water and sanitation-2012 Update. New York: WHO Press; 2012.

5. Walters SP, Gannon VPJ, Field KG. Detection of Bacteroidales fecal indicators and the zoonotic pathogens E. coli 0157:H7, salmonella, and campylobacter in river water. Environ Sci. Technol. 2007;41(6):1856-62.

6. Madec J-Y, Lazizzera C, Châtre P, Meunier D, Martin S, Lepage G, et al. Prevalence of fecal carriage of acquired expandedspectrum cephalosporin resistance in Enterobacteriaceae strains from cattle in France. J Clin Microbiol. 2008;46(4):15667.

7. Mercado-Blanco J, Bakker PA. Interactions between plants and beneficial Pseudomonas spp.: exploiting bacterial traits for crop protection. Antonie Van Leeuwenhoek. 2007;92(4):367-89.

8. Akhtar S, Riaz M, Ismail T, Farooq U. Microbiological safety of street vended fresh fruit juices, drinks and conventional blends in Multan-Pakistan. Pak J Agri Sci. 2013;50(2):255-60.

9. Had S, Amer, Ustovi, Smajlovi J, Ahmetagi S. Distribution of nosocomial infections caused by Klebsiella pneumoniae ESBL strain. J Environ Occup Sci. 2012;1(3):1416.

10. Zhu H, Hart CA, Sales D, Roberts NB. Bacterial killing in gastric juice - effect of $\mathrm{pH}$ and pepsin on Escherichia coli and Helicobacter pylori. J Med Microbiol. 2006;55(Pt9):1265-70.

11. Semenov AV, van Bruggen AHC, van Overbeek L, Termorshuizen AJ, Semenov AM. Influence of temperature fluctuations on Escherichia coli 0157:H7 and Salmonella enterica serovar Typhimurium in cow manure. FEMS Microbiol Ecol. 2007;60(3):419-28.

12. Alvarez-Ordóñez A, Begley $\mathrm{M}$, Prieto M, Messens W, López M, Bernardo A, et al. Salmonella spp. survival strategies within the host gastrointestinal tract. Microbiology. 2011;157(Pt 12):3268-81.

13. Momtaz H, Dehkordi FS, Rahimi E, Asgarifar A. Detection of Escherichia coli, Salmonella species, and Vibrio cholerae in tap water and bottled drinking water in Isfahan, Iran. BMC Public Health. 2013;13:556. 